object, where it rests for a short time, and then resumes the upright attitude. A large species, attached to seaweed.

\title{
Vorticella zealandica.
}

Body attenuate, from two to three times as long as the greatest breadth, tapering downwards, considerably constricted below the peristome, then swelling for rather more than half the length, when it again becomes constricted; then a nearly circular swelling, giving the posterior end an unusually blunt appearance.

Apparently striated perpendicularly; but of this I am not certain, as at some times the striations were seen, while at others they disappeared, as though at the will of the animal. Pedicle slight, four times the length of the body. Length of body $\frac{1}{2} \frac{1}{00}$ inch.

Hab. Pond in Newtown Park, Wellington.

LVII.-Descriptions of new Species of Epitola from Cameroons dec. in the Collection of Henley Grose Smith. By W. F. Kirby, F.E.S.

In order to avoid the premature multiplication of genera I employ Epitola in the extended sense in which it was used by the late Mr. Hewitson; but it must not be forgotten that there are three very distinct forms in the genus:-(1) Epitola elion, Doubl. \& Hew. (the type), a large insect, with the hind margin of the fore wings strongly emarginate ; (2) E. ceraunia, Hew., a smaller insect, with rather long fore wings and the hind margin oblique and less strongly emarginate; and (3) the comparatively small species with rounded wings which form the bulk of the genus as it stands at present. I believe the last are sometimes arranged under Phytala, with the type of which they have also but little resemblance.

\section{Epitola urania.}

Expands $2 \frac{2}{3}$ inches.

Male.-Fore wings: costa strongly arched, tip rounded and produced, the hind margin deeply concave and then rounded to the inner margin. Hind wings rounded, more obtusely towards the inner margin.

Wings rich blue, shading into purple towards the edges; 
costa black as far as the subcostal nervure, but the blue extending nearly to its edge for about the middle third of its length; apical third of costa black, its boundary, except that the blue projects slightly into it beyond the cell, falling nearly straight to the extremity of the hind margin, where the black border narrows and disappears. Hind wings with a narrow black border, extending round the hind and inner margins, narrowest on the lower half of the hind margin. Underside: fore wings light brown, varied with grey, and, towards the tips, with purplish and bronzed reflections; extremity of the cell with two whitish spots, the largest within the cell, the other forming the middle of a curved series of five spots, the four outermost being bright blue; beyond these is another row of five whitish spots, two near the costa and three towards the hind margin, the series being interrupted between; but between this empty space and the hind margin are four more whitish spots, arranged in pairs. Hind wings iridescent purple and yellow, the costa bright golden yellow above the subcostal nervure to nearly half its length; between the median nervules near their origin are two whitish spots.

Hab. Cameroons.

Allied to E. elion, Doubl. \& Hew.

This beautiful species is one of the largest of the Lycænidæ.

\section{Epitola Dewitzi.}

Expands from $1 \frac{3}{4}$ to nearly 2 inches.

Male.-Fore wings triangular; costa arched at the base, tip projected; hind margin slightly emarginate about the middle and sloped gradually to the anal angle. Hind wings rounded, curved outwards; anal angle very slightly rounded off. Fore wings black, with a deep blue band extending from the base between the median and submedian nervures nearly to the extremity of the wing, and a curved row of four blue spots above it, two at the end of the cell and two linear between these and the larger blue space. Hind wings deep blue, the costa and inner margin broadly and the hind margin narrowly bordered with black. Underside : fore wings brown, with two longitudinal spots at the end of the cell, and an irregular curved row of white spots near the hind margin; underside yellowish brown, with a broad white subcostal band; a curved white band running from the base of the inner margin round nearly to the tip, and an oval white spot between.

Female.-Wings longer, fore wings with the hind margin oblique, hardly emarginate; the markings similar, but the 
blue colour paler; two bluish-white spots at the end of the cell, and an obsolete row of pale bluish spots curving beyond the cell from the end of the main blue stripe to the costa. Hind wings with a uniformly broad blackish-brown border. Underside: fore wings nearly as in the male, but tinged with yellowish grey towards the tip, and narrowly along the costa: hind wings yellowish grey, shading into light brownish in the cell.

Hab. Cameroons.

Closely allied to E. ceraunia, Hew., from which the under surface of the male hardly differs.

\section{Epitola dunia.}

Expands $1 \frac{1}{2}$ inch.

Male.-Wings broad; fore wings with the costa arched, the hind margin nearly straight; hind wings moderately rounded, anal angle only slightly rounded off. Fore wings black, with a large purplish-blue patch on the inner margin at one fourth of its length, ceasing before the anal angle, and continued upwards into the cell; the base of the cell and inner margin is slightly dusted with blue : hind wings purplish blue, the costa above the cell and the inner margin black, the hind margin more narrowly ; the upper part of the discocellular marked with black. Underside light brown: fore wings with a large space on the outer half of the inner margin whitish : hind wings with scattered white scales, having a tendency to run into rows.

$H a b$. Cameroons.

Allied to E. cercene, Hew., but less blue above, and with no distinct markings on the underside.

\section{Epitola marginata.}

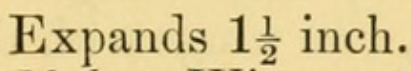

Male.-Wings with the fringes denticulated; fore wings broad, hind margin rounded off towards the anal angle; hind wings rather short, the hind margin gradually rounded; fore wings blue, broadly black at the base of the cell, above the cell, and at the tip and hind margin, nearly to the anal angle, and the discocellular also marked with black: hind wings blue, the costa above the cell, the hind margin narrowly, and the inner margin moderately bordered with black; the incisions on all the wings dusted with white: hind wings brown, dusted with white, in such a manner as to form irregular obsolete zigzag lines and blotches, especially towards 
the inner margin of the fore wings and the hind margin of the hind wings.

$H a b$. Cameroons.

Allied to E. dunia.

\section{Epitola versicolor.}

Expands from $1 \frac{1}{4}$ to over $1 \frac{1}{2}$ inch.

Male.-Fore wings rather short and broad, hind margin nearly straight, slightly rounded above the anal angle; hind wings moderately rounded : fore wings brown, darkest on the hind margin, pale blue at the base in the cell and below; the discocellular is conspicuously black; beyond the cell is a broad, curved, white band, narrowing from the inner margin nearly to the costa, before which it ceases : hind wings brown, pale blue in the cell and below; hind margin shading into darker brown. Under surface light brown, with numerous traces of irregular transverse pale lines; the white transverse band in the middle of the fore wings as above, except that it is of a more yellowish white beyond the cell and towards the costa.

Female similar, but larger and paler. Fore wings with the white band not extending to the inner margin : hind wings uniform pale brown. The underside is of a light greyish brown, with no yellow shade in the white band; the discocellular is nearly surrounded with white, and there are a few other indistinct whitish markings.

Hab. Cameroons.

An aberrant species of the $E$. cercene group.

\section{Epitola badia.}

Expands $1 \frac{1}{4}$ inch.

Male.-Wings short, moderately broad; hind margin of fore wings gradually curved; wings blue, fore wings with the costa above the cell and the tip and hind margin black, narrowing to the anal angle; no mark on the discocellular, but the median nervure with a thick blackish streak at the base : hind wings with the costa above the cell, the inner margin, and the upper part of the hind margin with a moderately broad black border; the lower part of the hind margin narrowly edged with black. Underside greyish brown, paler on the inner margin of the fore wings, and with very slight traces of obsolete zigzag markings.

Hab. Cameroons.

Allied to E. zelza, Hew. 
Mr. H. Grose Smith on Ornithoptera Victoriæ, Gray.

\section{Epitola uniformis.}

Expands about $1 \frac{1}{4}$ inch.

Shape of E. badia, which it much resembles; the blue is paler, especially in the female, in which sex the brown border of the hind wings is much broader; there is a conspicuous blackish spot at the end of the cell of the fore wings, which at once distinguishes it. Underside uniform brown, greyer and with a pale space on the inner margin of the fore wings in the female.

Hab. Lagos ( $\left.\sigma^{\top}\right)$, Cameroons ( $q$ ).

Allied to E. zelza, Hew., and E. badia.

LVIII.-Description of the hitherto unknown Male of Ornithoptera Victoriæ, Gray. By H. Grose Smith.

\section{Ornithoptera Victorice, Gray.}

Male.-Upperside. Anterior wings velvety black, the basal three fourths of the cell and two thirds of the space beneath the cell to the inner margin golden green. Towards the apex is another large patch of golden green, triangular, the base of the triangle being just below the first discocellular nervule; between the basal and apical patches of colour is a brownishblack sericeous space.

Posterior wings velvety black, the space between the costa and the cell, the basal part of the cell, and the basal part of the median nervules green; three submarginal oval goldengreen spots between the nervules, the first being situate below the second subcostal nervule, and each of the lower spots being centred with a bright orange ovate spot; the rest of the wings, except the fold, more or less irrorated with green; the abdominal fold only extends two thirds the length of the wings, causing the appearance of an excavation at the anal angle. Both wings are comparatively narrow, the cell on the upper wings is very broad, and on the lower wings is elongated.

Underside. Both wings golden green. Anterior wings, costa, and nervures black; an irregular black patch towards the upper part of the end of the cell and beyond it, with a few scattered green scales, and four submarginal lunular black spots between the nervules; the space above the inner margin, almost as far as the cell, devoid of scales and brownish grey. Posterior wings with elongated or ovate black spots Ann. \& Mag. N. Hist. Ser. 5. Vol. xix. 


\section{$2 \mathrm{BHL}$ Biodiversity Heritage Library}

Kirby, W. F. 1887. "LVII.-Descriptions of new species of Epitola from Cameroons \&c. in the collection of Henley Grose Smith." The Annals and magazine of natural history; zoology, botany, and geology 19, 441-445. https://doi.org/10.1080/00222938709460278.

View This Item Online: https://www.biodiversitylibrary.org/item/55145

DOI: https://doi.org/10.1080/00222938709460278

Permalink: https://www.biodiversitylibrary.org/partpdf/57023

\section{Holding Institution}

Smithsonian Libraries

\section{Sponsored by}

Smithsonian

\section{Copyright \& Reuse}

Copyright Status: Public domain. The BHL considers that this work is no longer under copyright protection.

This document was created from content at the Biodiversity Heritage Library, the world's largest open access digital library for biodiversity literature and archives. Visit BHL at https://www.biodiversitylibrary.org. 